\title{
Analisis Pengaruh Non Performing Loan, Dana Pihak Ketiga, Terhadap Pembiayaan Akad Mudharabah di Bank Syariah
}

\author{
Riyan Pradesyah \\ Dosen Fakultas Agama Islam UMSU \\ (Email : rriyanpradesyah@yahoo.com)
}

\begin{abstract}
ABSTRAK
Penelitian ini bertujuan untuk mengetahui pengaruh Non Performing Finance, dan Dana Pihak Ketiga terhadap pemberian pembiayaan mudharabah. Sampel yang digunakan adalah NPF, DPK dan Mudharabah, dari bulan januari 2012 sampai Desember 2015. Pendekatan penelitian yang digunakan penelitian kuantitatif dengan analisis regresi berganda, dengan menggunakan SPSS. Dari hasil penelitian yang dilakukan pada alpha 5\%, penulis menyimpulkan bahwa hasil analisis pengaruh Non Performing Loan, dan Dana Pihak Ketiga, terhadap pembiayaan akad Mudharabah di Bank Syariah, secara bersamaan berepengaruh dengan tingkat alpha 5\% dan nilai palue nya adalah 0,00. Sedangkan secara tunggal, variabel Non Performing Finance sebesar 0,570 atau 5,70\%. Dan variabel Dana Pihak Ketiga berpengaruh sebesar 0,413 atau 4,13\%. Itu berarti, NPF mempunyai pengaruh secara dominan terhadap pembiayaan mudharabah.
\end{abstract}

Kata Kunci : Non Performing Finance (NPF), Dana Pihak Ketiga (DPK), Pembiayaan Mudharabah.

\section{A. PENDAhuluan}

Perkembangan lembaga keuangan syariah di indonesia, telah mengalami peningkatan dari tahun ketahunnya. Peningkatan lembaga keuangan syariah, menjadi suatu hal yang sangat menggembirakan bagi umat muslim. Sebab, adanya peningkatan tersebut, merupakan suatu bukti nyata, bahwa prinsip syariah dapat diterima oleh masyarakat luas, termasuk Indonesia. Peningkatan tersebut tentu bukanlah hal yang baru terjadi, tetapi sudah mengalami peningkatan di beberapa tahun ke depan. Peningkatan-peningkatan tersebut, tentu saja tidak terlepas dari yang namanya sosialisasi, yang dilakukan oleh para aktifis ekonomi islam, akademisi ekonomi islam, dan praktisi lembaga keuangan syariah. Sosialisasi tersebut tentu saja berpengaruh besar terhadap perkembangan lembaga keuangan syariah. Sebab, adanya sosialisasi, maka masyarakat akan paham apa yang dimaksud dengan lembaga keuangan syariah, dan perbedaanya 
dengan lembaga keuangan

konvensional.

Sosialisasi yang dilakukan oleh para praktisi, meliputi tentang penerapan-penerapan akad yang ada di lembaga keuangan syariah, dimulai dari akad yang digunakan dalam penghimpunan dana, sampai pada akad yang digunakan dalam penyaluran dana. Sedang pada akedemisi, sosilaisasi yang dilakukan adalah secara keseluruhan, mulai dari munculnya perbankan syariah atau lembaga keuangan syariah, sampai pada perkembangan lembaga keuangan syariah, baik di Indonesia, maupun di belahan dunia lainnya. Sosialisasi-sosialisasi tersebut tentu saja berpengaruh terhadap pemahaman masyarakat, terkait dengan ilmu yang berkembang, dan pemahaman-pemahaman terhadap ekonomi islam dan lembaga keuangan syariah.

Kemunculan perbankan syariah ditengah-tengah masyarakat bukanlah hal yang baru di dalam kehidupan. Melainkan, suatu permintaan masyarakat untuk hidup dalam norma-norma islam. Untuk itu, perbankan syarriah menjawab semua permintaan masyarakat Indonesia, yang dimana sebahagian penduduknya adalah umat muslim.

Semakin berkembanganya bank syariah di Indonesia, tidak luput dari perhatian masyarakat yang ingin melihat, memperhatikan, atau mempraktekan secara langsung tentang apa yang ada di dalam perbankan syariah. Dimulai dari penggunaan produk, pelayanan, penerapan fatwa DSN, hingga pada akuntasi syariah yang diterbitkan untuk akad-akad yang ada di perbankan syariah. Yang dimaksud dengan akad di sini ialah kesepakatan dalam suatu perjanjian antara dua pihak atau lebih untuk melakukan dan atau tidak melakukan perbuatan hukum tertentu. ${ }^{1}$

Perbankan syariah juga mempunyai fungsi yang sama dengan bank pada umumnya, yaitu menerima simpanan uang, meminjamkan uang, dan memberikan jasa. ${ }^{2}$ Atau dalam kata lain, bank mempunyai fungsi untuk menyimpan dan menyalurkan dana kepada masyarakat. Hanya saja, bank syariah melakukan kegiatan transaksi tersebut menggunakan

\footnotetext{
1 Mardani, Fiqih Ekonomi Syariah, (Jakarta : Kencana Pramedia, 2012), hal. 72

2 Karim Adiwarman, Bank islam, (Jakarta : Grafindo Persada, 2011), hal. 18
} 
prinsip-prinsip yang sesuai dengan syariah.

Bank syariah juga mempunyai berbagai macam produk yang dapat digunakan oleh para masyarakat. Diantaranya ialah produk pendanaan, pengkreditan, penyimpanan, dan produk lainnya yang dijalankan sesuai dengan prinsip syariah. Pembiayaan yang dilakukan biasanya berdasarkan besar kecilnya dana pihak ketiga yang ada di lembaga keuangan syariah. Untuk itu, disini penulis ingin meneliti dengan judul "Analisis Pengaruh Non Performing Loan, Dana Pihak Ketiga, Terhadap Pembiayaan Akad Mudharabah di Bank Syariah"

\section{B. TINJAUAN PUSTAKA.}

1. Perbankan Syariah.

Bank merupakan perusahaan yang bergerak dalam bidang keuangan, artinya aktivitas perbankan selalu berkaitan dalam bidang keuangan. Sehingga berbicara mengenai bank tidak terlepas dari masalah keuangan. ${ }^{3}$ Berbicara tentang bank syariah, berarti kita berbicara tentang akad-akad atau landasan hukum perbankan syariah. Seperti yang sudah diuraikan di atas, landasan hukum perbankan syariah ialah, Al-Quran dan Hadits. Perbankan syariah juga diatur dalam

Kasmir, Bank dan Lembaga Keungan Lainnya, (Jakarta : Raja Grafindo, 2008), Hal.25-26
Undang-undang, Fatwa DSN. Sedangkan dalam penjuranalan atau penetapan akuntansi di dalam pembukan, bank syariah juga di atur dalam PSAK. Dalam lembaga keuangan syariah Dewan Syariah Nasional (DSN) yang merupakan bagian dari MUI mempunyai peranan yang membuat fatwa terkait produk keuangan syariah. ${ }^{4}$

Perkembangan bank-bank syariah di Indonesia dimulai pada priode 1980-an, dimana diskusi mengenai bank syariah sebagai pilar ekonomi islam mulai dilakukan. Para tokoh yang terlibat dalam kajian tersebut adalah Karnaen A. Perwataatmadja, M. Dawan Raharjo, A.M. Saefudin, M. Amien Azis dan lain-lain. ${ }^{5}$ Bebrapa uji coba telah dilakukan oleh mereka, dimuali dari BMT Salman, bandung, yang sempat tumbuh mengensankan.dan kembali lagi dibuka di Jakarta dengan bentuk lembaga serupa dalam bentuk koperasi, yakni koperasi Ridho Gusti. Mereka lebih berfokus pada lembaga keuangan kecil terlebih dahulu, disbanding dengan lembaga

\footnotetext{
4 Rizal Yaya, dkk, Akuntansi Perbankan Syariah, (Jakarta : Salemba Empat, 2009), Hal. 27

5 Antonio Muhammad Syafi'I, Bank Syariah, (Jakarta : Gema Insani, 2001), hal. 25
} 
keuangan yang lebih besar seperti bank.

Pada tahun 1992, bank muamalat telah berdiri di Indonesia. meskipun perkembangannya agak melambat disbanding dengan negara-negara muslim lainnya. Tetapi lambat laun, bank syariah di Indonesia terus berkembang hingga pada thun 2005 juml;ah bank syariah di Indonesia mencapai 20 unit. $^{6}$

Kemunculan bank modern pertama kali di dunia adalah mesir. Diawalai dengan pendirian Mit Ghamar Savings Bank di Mesir sebagai bank syariah modern pertama. Sebagai mana telah diketahui atas hal tersebut, dan kemudia menjadikan perkembangan bank syariah diseluruh dunia. ${ }^{7}$ Kemodernisasian yang terjadi di mesir, terus merambah pada bankbank syariah yang ada di dunia hingga sampai pada Indonesia. Sampai pada akhirnya, Negara Indonesia telah mengukuhkan atau telah membuat sebuah peraturan tentang perbankan syariah. Dumai

6 Karim Adiwarman, Bank Islam, (Jakarta : PT Raja Grafindo Persada, 2011), hal. 25.

${ }^{7}$ Sjahdeini Remy Sutan, Perbankan Syariah, (Jakarta : Kencana Prenadamedia Group, 2014), hal. 52. dari pengertian, sampai pada tahaptahap pelaksanaanya.

Pengertian Bank Syariah Menurut Undang-undang No.10 tahun 1998 bank syariah adalah Bank yang melaksanakan kegiatan usahanya berdasarkan prinsip syariah yang dalam kegiatannya memberikan jasa dalam lalu lintas pembayaran ${ }^{8}$

Perbankan syariah sebenarnya telah diatur dalam Undang-undang. Pasal 2 PBI No. 6/24/PBI/2004 Tentang Bank Umum yang Melaksanakan Kegiatan Usaha Berdasarkan Prinsip Syariah, memberikan definisi bahwa Bank umum syariah adalah bank yang melaksanakan kegiatan usaha berdasarkan prinsipsyariah yang dalam kegiatannya memberikan jasa dalam lalu lintas pembayaran. ${ }^{9}$

Secara garis besar hubungan ekonomi berdasarkan syariah Islam tersebut di tentukan oleh hubungan akad yang terdiri dari lima konsep dasar akad. Bersumber dari lima dasar konsep inilah dapat ditemukan

http://www.sarjanaku.com/2012/06/banksyariah-pengertian-prinsip-tujuan.html. Tanggal 15 Oktober 2015. melalui.http://www.banksyariah.net/2012/07/p engertian-bank-syariah_19.html.Tanggal 15 Oktober 2015. 
produk-produk lembaga keuangan bank syariah dan lembaga keuangan bukan bank syariah untuk dioperasionalkan. Kelima konsep tersebut adalah, sistem simpanan, bagi hasil, Margin Keuangan, Sewa, dan jasa (fee). Kelima konsep tersebutlah yang menjadikan bank syariah terus bergerak dan berkembang.

Adapun pengertian bank syariah menurut para ahli adalah sebagai berikut : Menurut Schaik, Bank Islam adalah sebuah bentuk dari bank modern yang didasarkan pada hukum Islam yang sah, dikembangkan pada abad pertama Islam, menggunakan konsep berbagi risiko sebagai metode utama, dan meniadakan keuangan berdasarkan kepastian serta keuntungan yang ditentukan sebelumnya.

Menurut Sudarsono, Bank Syariah adalah lembaga keuangan yang usaha pokoknya memberikan kredit dan jasa-jasa lain dalam lalu-lintas pembayaran serta peredaran uang yang beroperasi dengan prinsipprinsip syariah. Menurut Donna, Bank Syariah adalah lembaga keuangan yang beroperasi dengan tidak mengandalkan pada bunga yang usaha pokoknya memberikan pembiayaan dan jasa-jasa lainnya dalam lalu-lintas pembayaran serta peredaran uang yang pengoperasiannya sesuai dengan prinsip syariat Islam. ${ }^{10}$

Dalam perbankan syaria, keuangna syariah merupakan sistem keuangan yang menjebatani anatara pihak yang membutuhkan dana dengan pihak yang memiliki dana melalui produk jasa keuangan yang sesuai dengan prinsip-prinsip syariah. Sedangkan arti dari prinsip syariah adalah prinsip hukum islam dengan kegiatan perbankan dan keuangan berdasarkan fatwa yang dikeluarkan oleh lembaga yang memiliki kewenangan dalam penetapan fatwa di bidang syariah. ${ }^{11}$

2. Non Performing Loan.

Salah satu resiko yang dihadapi oleh bank adalah resiko tidak terbayarnya kredit yang telah diberikan kepada debitur atau disebut dengan resiko kredit. Suatu resiko akibat kegagalan atau ketidakmampuan nasabah mengembalikan jumlah pinjaman yang diterima dari bank beserta bunganya

\footnotetext{
10 Diakses melalui. http://rapraniji.blogspot.com/2010/10/banksyariah.html. 12 oktober 2015

11 Soemitra Andri, Bank dan Lembaga Keuangan Syariah, ( Jakarta : Kencana, 2009), Hal 19.
} 
sesuai dengan jangka waktu yang telah ditetapkan atau dijadwalkan..

Resiko kredit di dalamnya termasuk non performing finance. Non performing finance(NPf) adalah pembiayaan yang bermasalah dimana tidak dapat memenuhi pembayaran tunggakan peminjaman dan marjin/bagi hasil dalam jangka waktu yang telah disepakati dalam perjanjian.

Hal ini juga dijelaskan dalam Standar Akuntansi Keuangan No. 31 (revisi 2000) yang menyebutkan bahwa : "kredit non performing pada umumnya merupakan kredit yang pembayaran angsuran pokok/atau bunganya telah lewat sembilan puluh hari atau lebih setelah jatuh tempo atau kredit yang pembayarannya secara tepat waktu sangat diragukan.”

Kredit bermasalah biasanya timbul dari penunggakan nasabah yang melebihi ambang batas. Bila seharusnya nasabah akan mengembalikan uangnya tanggal 2 januari, nasabah malah tidak membayarnya sama sekali. Itulah sebabnya, lembaga keuangan mengalami non performing loan. Yang termasuk ke dalam non performing loan adalah kredit kurang lancar, kredit diragukan dan kredit macet. Menurut Surat Edaran Bank Indonesia No. 3/30/DPNP Tanggal 14 Desember 2001, NPL dapat dihitung dengan rumus $:^{12}$

NPL = kredit kurang lancar + kredit diragukan + kredit macet Total kredit yang diberikan Peningkatan NPF dalam jumlah yang banyak dapat menimbulkan masalah bagi kesehatan bank, oleh karena itu bank dituntut untuk selalu menjaga kredit tidak dalam posisi NPF yang tinggi.Agar dapat menentukan tingkat wajar atau sehat maka ditentukan ukuran standar yang tepat untuk NPF. Dalm hal ini Bank Indonesia menetapkan bahwa tingkat NPF yang wajar adalah $\leq 5 \%$ dari total portofolio kreditnya.

Setiap terjadi pembiayaan bermasalah maka bank syariah akan berupaya untuk menyelamatkan pembiayaan, berdasarkan Peraturan Bank Indonesia Nomor 13/9/PBI/2011 Tentang perubahan atas Peraturan Bank Indonesia Nomor 10/PBI/2008 Tentang Restrukturisasi Pembiayaan Bagi Bank Syariah dan Unit Usaha Syariah. Restrukturisasi Pembiayaan adalah upaya yang dilakukan Bank

\footnotetext{
${ }^{12}$ www.bi.go.id
} 
dalam rangka membantu nasabah agar dapat menyelesaikan kewajibannya, antara lain melalui:

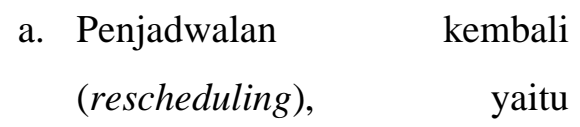
perubahan jadwal pembayaran kewajiban nasabah atau jangka waktunya

b. Persyaratan kembali (reconditioning), yaitu perubahan sebagian atau seluruh persyaratan Pembiayaan tanpa menambah sisa pokok kewajiban nasabah yang harus dibayarkan kepada Bank, antara lain meliputi:

1) Perubahan jadwal pembayaran;

2) Perubahan jumlah angsuran;

3) Perubahan jangka waktu;

4) Perubahan nisbah dalam pembiayaan mudharabah atau musyarakah;

5) Perubahan proyeksi bagi hasil dalam pembiayaan mudharabah atau musyarakah; dan/atau:

6) Pemberian potongan.

c. Penataan kembali (restructuring), yaitu perubahan persyaratan
Pembiayaan yang antara lain meliputi:

1) Penambahan dana fasilitas pembiayaan bank;

2) Konversi akad pembiayaan;

3) Konversi pembiayaan menjadi surat berharga syariah berjangka waktu menengah; dan/atau;

4) Konversi pembiayaan menjadi penyertaan modal sementara pada perusahaan nasabahyang dapat disertai dengan rescheduling atau reconditioning

Bank hanya dapat melakukan restrukturisasi pembiayaan terhadap nasabah yang memenuhi kriteria sebagai berikut :

a. Nasabah mengalami penurunan kemampuan pembayaran; dan

b. Nasabah memiliki prospek usaha yang baik dan mampu memenuhi kewajiban setelah restrukturisasi.

Restrukturisasi untuk Pembiayaan konsumtif hanya dapat dilakukan untuk nasabah yang memenuhi kriteria sebagai berikut:

a. Nasabah mengalami penurunan kemampuan pembayaran; dan 
b. Terdapat sumber pembayaran angsuran yang jelas dari nasabah dan mampu memenuhi kewajiban setelah restrukturisasi.

Restrukturisasi pembiayaan wajib didukung dengan analisis dan buktibukti yang memadai serta didokumentasikan dengan baik. Disamping 2 (dua) kriteria di atas maka bank syariah akan melakukan penyelamatan pembiayaan bermasalah dengan upaya restrukturisasi apabila nasabah masih mempunyai itikad baik dalam arti masih mau diajak kerjasama dalam upaya penyelamatan pembiayaan bermasalah, akan tetapi jika nasabah sudah tidak beritikad baik dalam arti tidak dapat diajak kerjasama dalam upaya penyelamatan pembiayaan bermasalah maka bank syariah akan melakukan upaya penyelesaian pembiayaan bermasalah.

\section{Unsur Pembiayaan}

Untuk mendapatkan pembiayan disuatu lembaga keuangan, kita perlu mengetahui unsur-unsur apa saja yang harus kita penuhi dalam mendapatkan pembiayaan tersebut. Persyaratan yang diajukan bank kepada nasabah biasanya berupa perjanjian yang nantinya akan di sepakati oleh kedua belah pihak. Unsur-usur yang diberikan oleh bank konvensional dan bank syariah memang sangat berbeda, dapat dilihat dari cara mereka menyajikan suatu perjanjian yang dapat menarik nasabah. Adapun unsure-unsur yang terkandung dalam kedua bank tersebut, adalah sebagai berikut. Adapun unsur-unsur pembiayaan Bank syariah adalah sebagai berikut $:^{13}$

a) Bank Syariah merupakan badan usaha yang memberikan pembiayaan kepada pihak lain yang membutuhkan.

b) Mitra Usaha/Partner, merupakan pihak yang mendapatkan pembiayaan dari bank syariah, atau pengguna dana yang disalurkan oleh bank syariah.

c) Kepercayaan (Trust), Bank syariah memberikan kepercayaan kepada pihak yang menerima pembiayaan bahwa mitra akan memenuhi kewajiban untuk mengembalikan dana bank syariah sesuai dengan jangka waktu tertentu yang diperjanjikan.

d) Akad, merupakan suatu kontrak pernajian atau kesepakatan yang dilakukan antara bank syariah dan pihak nasabah/ mitra.

\footnotetext{
${ }^{13}$ Drs. Ismail, MBA., Ak. Perbankan Syariah, (Jakarta : Kencana, 2014), Hal. 107108
} 
e) Risiko. Setiap dana yang disalurkan/diinvestasikan

oleh bank syariah selalu mengandung risiko kembalinya dana. Risiko pembiayaan merupakan kemungkinan kerugian yang akan ditimbulkan karena dana yang disalurkan tidak dapat kembali.

f) Jangka Waktu. Merupakan peridode waktu yang diperlukan oleh nasabah untuk membayar kembali pembiayaan yang telah diberikan oleh bank syariah.

g) Balas Jasa, sebagai balas jasa atas dana yang disalurkan oleh bank syariah, maka nasabah membayar sejumlah tertentu sesuai dengan akad yang telah disepakati antara bank dan nasabah.

Dari penjelasan unsure-unsur pembiayaan bank syariah di atas, dapat kita lihat dengan jelas. Bahwa bank syariah melakukan pembiayaan dengan landasan al-quran dan hadist, yang dimana dapat kita temui di dalam setiap pembiayaan atau akad yang digunakan oleh bank syariah. Seperti pembiayaan pada akad murabaha yang mempunyai landasan Al-quran, yaitu Q.S. AlBaqara : $275{ }^{14}$

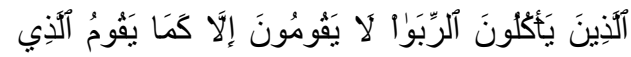

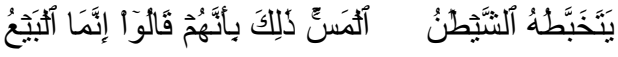

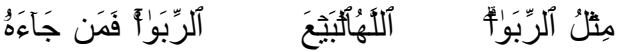

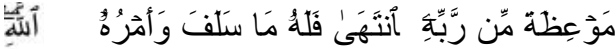

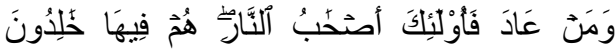
“orang-orang yang Makan (mengambil) riba tidak dapat berdiri melainkan seperti berdirinya orang yang kemasukan syaitan lantaran (tekanan) penyakit gila. Keadaan mereka yang demikian itu, adalah disebabkan mereka berkata (berpendapat), Sesungguhnya jual beli itu sama dengan riba, Padahal Allah telah menghalalkan jual beli dan mengharamkan riba. orang-orang yang telah sampai kepadanya larangan dari Tuhannya, lalu terus berhenti (dari mengambil riba), Maka baginya apa yang telah diambilnya dahulu (sebelum datang larangan); dan urusannya (terserah) kepada Allah. orang yang kembali (mengambil riba), Maka orang itu adalah penghuni-penghuni neraka; mereka kekal di dalamnya"

\footnotetext{
${ }^{14}$ Antonio Muhammad Syafi'I, Bank Syariah, ( Jakarta : Gema Insani, 2001), hal. 102
} 
Ayat tersebut diperkuat dengan

hadis Rasulullah yang diriwayatkan oleh Ibnu Majah.

Dari suhaib ar-Rumi. r.a. bahwa Rasulullah saw. bersabda, "tiga hal yang di dalamnya terdapat keberkahan; Jual beli secara tangguh, muqaradah, dan mencapur gandum dengan tepung untuk keperluhan rumah, bukan untuk dijual.” (HR.Ibnu Majah) ${ }^{15}$

Adanya landasan dari ayat dan hadits di atas, berate kita harus mengikuti apa yang telah menjadi dasar landasan pada akad murabaha di atas, atau pembiayaan yang ada di bank syariah dengan akad murabaha. Pada dasarkan, pembiayaan yang menggunakan akad murabahah juga atas ridha sama ridha, terkait dengan apa yang telah disepakati atas pembiayaan akad murabahah tersebut. Dengan demikian pada saat pelaksanaan atau penerapan perjanjian masing-masing pihak yang mengadakan perjanjian atau yang mengikatkan diri dalam perjanjian haruslah mempunyai interpretasi yang sama tentang apa yang telah mereka perjanjikan.

\footnotetext{
${ }^{15}$ Ibid.
}

\section{Akad Mudharabah}

Mudharabah berasal dari kata dharb, berarti memukul atau berjalan dimana pengertian memukul atau berjalan lebih tepat adalah proses seseorang memukulkan kakinya dalam menjalankan usaha. ${ }^{16}$ Secara teknis Mudharabah adalah suatu akad kerjasama atau persetujuan kongsi usaha antara dua pihak dimana pihak pertama (shahibul maal) menyediakan seluruh dana (100\%) dan pihak kedua (mudharib) bertanggung jawab atas pengelolaan usaha dimana keuntungannya dibagikan sesuai dengan rasio bagi hasil yang telah disepakati bersama. ${ }^{17}$

Seperti pada akad ekonomi islam lainnya, akad mudharabah juga mempunyai landasan Al-Quran dan hadist. Di mana, landasan keduanya lah yang memperkuat tentang kehalan suatu produk yang ada di bank syariah. Adapun landasan mudharabah menurut Al-Quran adalah : ${ }^{18}$

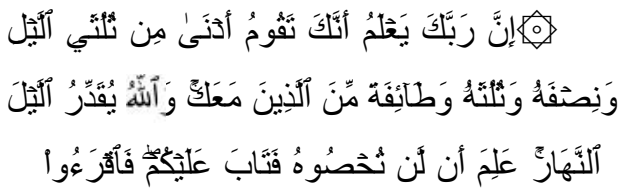

16 Adiwarman A.Karim, Analisis Fiqih dan Keuangan, (Jakarta : Pt Raja Grafindo, 2011), hal:205

${ }^{17}$ Antonio Muhammad Syafii, Bank Syariah, (Jakarta : Gema Insani, 2001), hal. 95 ${ }^{18}$ Ibid. 


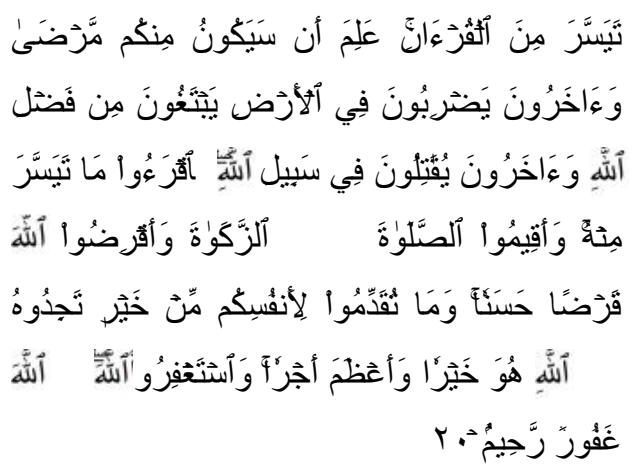

20. Sesungguhnya Tuhanmu mengetahui bahwasanya kamu berdiri (sembahyang) kurang dari dua pertiga malam, atau seperdua malam atau sepertiganya dan (demikian pula) segolongan dari orang-orang yang bersama kamu. Dan Allah menetapkan ukuran malam dan siang. Allah mengetahui bahwa kamu sekalikali tidak dapat menentukan batasbatas waktu-waktu itu, maka Dia memberi keringanan kepadamu, karena itu bacalah apa yang mudah (bagimu) dari Al Quran. Dia mengetahui bahwa akan ada di antara kamu orang-orang yang sakit dan orang-orang yang berjalan di muka bumi mencari sebagian karunia Allah; dan orang-orang yang lain lagi berperang di jalan Allah, maka bacalah apa yang mudah (bagimu) dari Al Quran dan dirikanlah sembahyang, tunaikanlah zakat dan berikanlah pinjaman kepada Allah pinjaman yang baik. Dan kebaikan apa saja yang kamu perbuat untuk dirimu niscaya kamu memperoleh (balasan)nya di sisi Allah sebagai balasan yang paling baik dan yang paling besar pahalanya. Dan mohonlah ampunan kepada Allah; sesungguhnya Allah Maha Pengampun lagi Maha Penyayang" (QS. Al-Muzammil:20)

Dimana yang menjadi wajhuddilalah atau argumen dari penjelasan surat Q.S. Muzammil: 20 adalah adanya kata yadhribun yang sama dengan akar kata mudharabah dimana berarti melakukan suatu perjalanan usaha.

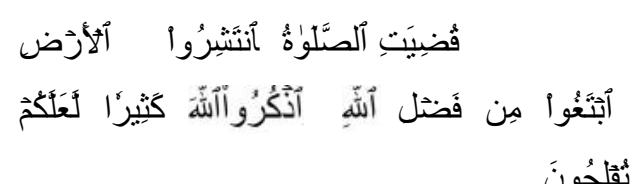

"Apabila telah ditunaikan shalat, maka bertebaranlah kamu di muka bumi; dan carilah karunia Allah dan ingatlah Allah banyak-banyak supaya kamu beruntung."(QS. alJumu'ah:10)

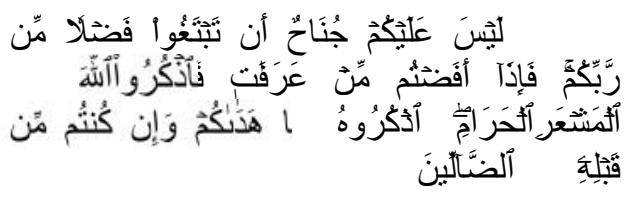

"Tidak ada dosa bagimu untuk mencari karunia (rezeki hasil perniagaan) dari Tuhanmu. Maka apabila kamu telah bertolak dari 'Arafat, berdzikirlah kepada Allah di Masy'arilharam. Dan berdzikirlah (dengan menyebut) Allah sebagaimana yang ditunjukkan-Nya kepadamu; dan sesungguhnya kamu sebelum itu benar-benar termasuk orang-orang yang sesat.(QS. alBaqarahh:198)

Surah al-Jumu'ah: 10 dan alBaqarah:198 sama-sama mendorong kaum muslimin untuk melakukan perjalanan usaha. 
Sedangkan hadits Rasulullah, yang memperkuat akad mudharabah adalah: ${ }^{19}$

"Diriwayatkan dari Ibnu Abbas, bahwa Sayyidina Abbas bin Abdul Muntalib jika memberikan dana kepada mitra usahanya secara Mudharabah ia mensyaratkan agar dananya tidak dibawa mengarungi lautan, menuruni lembah yang berbahaya, atau membeli ternak. Jika menyalahi aturan tersebut, maka yang bersangkutan bertanggung jawab atas dana tersebut. Disampaikanlah syarat-syarat tersebut kepada Rasulullah, dan Rasulullah pun membolehkannya."(HR. Thabrani).

"Tiga perkara yang mengandung berkah adalah jual-beli yang ditinggalkan, melakukan qiradh (memberi modal kepada orang lain), dan yang mencampurkan gandum dengan jelas untuk keluarga, bukan untuk diperjual belikan." (HR. Ibnu Majah dan shuhaib)

“Dari 'Ala' bin Abdurrahman dari ayahnya dari kakeknya bahwa Utsman bin 'Affan memberinya harta dengan cara qiradh yang dikelolanya, dengan ketentuan keuntungan dibagi

\footnotetext{
${ }^{19}$ Ibid, Hal. 96
}

di antara mereka berdua." (HR.Imam Malik)

Itulah ayat-ayat Al-Quran dan Hadits yang melandasi tentang akad Mudharabah, di dalam pelaksaan akadnya. Di dalam akad mudharabah ada unsur syirkah atau kerja sama, hanya saja bukan kerja sama antara harta dengan harta atau tenaga dengan tenaga, melainkan antara harta dengan tenaga. Disamping itu, juga terdapat unsur syirkah (kepemilikan bersama) dalam keuntungan. Namun apabila terjadi kerugian maka kerugian tersebut oleh pemiik modal, sedangkan pengelola tidak dibebani kerugian, karena ia telah rugi tenaga tanpa keuntungan.

Dari definisi tersebut dapat dipahami bahwa mudharabah adalah suatu akad atau perjanjian antara dua orang atau lebih, dimana pihak pertama memberikan modal usaha, sedangkan pihak lain menyediakan tenaga dan keahlian, dengan ketentuan bahwa keuntungan dibagi di antara mereka sesuai dengan kesepakatan yang mereka tetapkan bersama.

\section{METODE PENELITIAN} Variabel yang digunakan
dalam penelitian ini adalah Non
Performing Finance (NPF), Dana 
Pihak Ketiga (DPK), dan Pembiayaan

Mudharabah. Penelitian ini dilakukan dari tahun 2012-2015. Penelitian ini dilakukan pada bank umum syariah yang ada di Indonesia, dengan mengambil data yang dipublikasikan oleh Bank Indonesia. Untuk variabel Non Performing Finance (X1), Dana Pihak Ketiga (DPK), dan Pembiayaan Mudharabah (Y).

Model Analisis pengaruh Non Performing Finance (NPF), Dana Pihak Krtiga, terhadap Pimbiayaan Mudharabah menggunakan data panel atau pooled data yang merupakan kombinasi dari data yang disusun berdasarkan urutan waktu. Penelitian ini menggunakan analisis pendekatan secara sederhana menggabungkan seluruh data time series dan crosssection dengan mengestimasi data panel, dengan persamaan sebagai berikut $:^{20}$

$\mathrm{Y}=\mathrm{f}(\mathrm{X} 1, \mathrm{X} 2, \mathrm{X} 3)$

Dari persamaan (3.1) dan (3.2) diperoleh :

$\mathrm{Y}=\mathrm{A} X 1^{\beta 1} \mathrm{X} 2^{\beta 2} \mathrm{X} 3^{\beta 3}$

Regresi data panel dapat dimodelkan sebagai berikut :

\footnotetext{
${ }^{20}$ Gujarati, Damodar. Ekonometri Dasar , (Jakarta, Erlangga,2004)
}

$$
\text { Yit }=\alpha+\alpha i+\text { Xit } \beta+\text { Eit. } \ldots \text { (3.3) }
$$

Dimana:

$\alpha=$ Konstanta

$\beta=$ Vektor berukuran $\mathrm{P} \quad \mathrm{x} \quad 1$ merupakan parameter hasil estimasi Xit = Observasi ke-it dari $\mathrm{P}$ variabel bebas

$\alpha \mathrm{i}=$ efek individu yang berbedabeda untuk setiap individu ke- $i$

Eit = error regresi seperti halnya pada model regresi klasik.

Berdasarkan persamaan (3.1),(3.2), (3.3),(3.4), diperoleh model data panel di formulasikan, sebagai berikut:

$\mathrm{Y}(\mathrm{PDRB}) \quad=\alpha+\beta 1 \mathrm{X} 1+\beta 2 \mathrm{X} 2+$ $\beta 3 \times 3+$ ei

Dimana :

Y : Pembiayaan Mudharabah

$\mathrm{X} 1$ : Non Performing Finance

X2: Dana Pihak Ketiga

$\beta 1, \beta 2, \beta 3$ : Koefisien masing-masing variabel

$\begin{array}{ll}\alpha & : \text { Konstanta } \\ \text { ei } & : \text { Error term }\end{array}$

Untuk memudahkan dalam pengolahan data tersebut maka sebagai alat analisis yang digunakan dalam mengolah data adalah program eviews versi 7. 
Untuk memilih model mana yang paling tepat digunakan untuk pengolahan data panel, maka terdapat beberapa pengujian yang dapat dilakukan, antara lain: ${ }^{21}$

a. Chow Test adalah pengujian untuk memilih apakah model yang digunakan Pooled Least Square Model/Common Effect Model atau Fixed Effect Model. Dalam pengujian ini dilakukan dengan hipotesis sebagai berikut:

Ho : Pooled Least Square Model/Common Effect Model

Ha : Fixed Effect Model

Jika chi square > 0.05 maka Ho ditolak

Jika chi square $<0.05$ maka Ho diterima

Dasar penolakan terhadap hipotesis nol tersebut adalah dengan menggunakan F Statistik. Dimana pengujian ini mengikuti distribusi $\mathrm{F}$ yaitu F K (N -1, NT $-\mathrm{N}-\mathrm{K})$. Jika nilai chow statistics (F statistic) hasil pengujian lebih besar dari $\mathrm{F}$ tabel, maka cukup bukti bagi kita untuk melakukan penolakan terhadap

\footnotetext{
${ }^{21}$ Rosadi, Dedi. Ekonometrika dan Analisis Runtun Waktu Terapan Dengan Eviews. Kajian Ekonomi, Bisnis dan Keuangan. (Yogyakarta : CV. Andi Offset,2011)
}

H0sehingga model yang kita gunakan adalah Fixed Effect Model, begitu juga sebaliknya.

b. Hausman Test adalah pengujian statistik sebagai dasar pertimbangan kita dalam memilih apakah menggunakan Fixed Effect Modelatau Random Effect Model. Pengujian ini dilakukan dengan hipotesis sebagai berikut:

Ho : Random Effects Model

Ha : Fixed Effects Model

Jika chi square > 0.05 maka Ho ditolak

Jika chi square $<0.05$ maka Ho diterima.

Alat Pengujian SignifikasiKoefesien Regresi $^{22}$

\section{Uji Statistik F}

Uji statistik $F$ digunakan untuk menguji adanya pengaruh variabel independen secara simultan/bersamasama terhadap variabel dependen. Pengujian ini didasarkan atas hipotesis nol $\left(\mathrm{H}_{\mathrm{o}}\right)$ yang hendak diuji, yaitu apakah semua parameter di dalam

\footnotetext{
${ }^{22}$ Gujarati, Damodar. Ekonometri Dasar , (Jakarta, Erlangga,2004)
} 
model sama dengan nol, atau $\mathrm{H}_{\mathrm{o}}: \alpha_{1}=$ $\alpha_{2}=\ldots=\alpha_{n}=0$, artinya apakah semua variabel independen bukan merupakan penjelas yang signifikan terhadap variabel dependen. Dan untuk $\mathrm{H}_{\mathrm{a}}$ : minimal satu dari $\alpha_{\mathrm{n}} \neq 0$.

Untuk menguji kedua hipotesis tersebut adalah dengan cara membandingkan nilai F-hitung dengan nilai F-tabel. Jika nilai F-hitung lebih besar nilai dari F-tabel maka hipotesis alternatifnya adalah bahwa semua variabel independen secara bersamasama mempengaruhi variabel dependen.

Rumusnya mencari F tabel adalah sebagai berikut :

$\mathrm{df} 1=\mathrm{k}-1$

$\mathrm{df} 2=\mathrm{n}-\mathrm{k}$

\section{Dimana :}

$\mathrm{k}$ : adalah jumlah variabel (bebas + terikat)

n : adalah jumlah observasi/sampel pembentuk regresi.

Adapun pengambilan keputusan dalam uji F:

$\mathrm{H}_{\mathrm{o}}$ ditolak jika $\mathrm{F}$ hitung $>\mathrm{F}$ tabel pada

$$
\alpha=5 \%
$$

$\mathrm{H}_{1}$ dterima jika $\mathrm{F}$ hitung $<\mathrm{F}$ tabel

$$
\text { pada } \alpha=5 \%
$$

2. Uji Koefisien Determinan $\left(\mathrm{R}^{2}\right)$
Untuk mengukur seberapa jauh kemampuan model dalam menerangkan variabel dependen dilakukan dengan melakukan penghitungan koefisien determinan $\left(\mathrm{R}^{2}\right)$. Nilai koefisien determinan antara nol dan satu, atau $0<\mathrm{R}^{2}<1$. Menurut Gujarati (2007), jika $\mathrm{R}^{2}=0$, keragaman Y sama sekali tidak dapat dijelaskan oleh keragaman $\mathrm{X}$. Sebaliknya jika $\mathrm{R}^{2}=100 \%$, keragaman $\mathrm{Y}$ dapat dijelaskan oleh keragaman $\mathrm{X}$, semua titik pengamatan berada pada garis regresi.

Untuk membandingkan dua $\mathrm{R}^{2}$, banyaknya peubah bebas dalam model harus diperhitungkan, yaitu dengan mempertimbangkan koefisien determinasi alternatif, atau dikenal sebagai $\mathrm{R}^{2}$ yang disesuaikan. "disesuaikan" disini berarti disesuaikan dengan derajat kebebasan.

$$
R^{2} \text { adjustet } \bar{R}^{2}=1-\frac{\sum^{e^{2}} /(n-k)}{\sum_{t}^{y_{t}^{2} /(n-1)}}
$$

dimana :

$$
\begin{array}{ll}
\sum e_{t}^{2} & =\sum\left(Y_{t}-\hat{Y}_{t}\right)^{2} \\
\mathrm{n} \quad & =\text { jumlah observasi, dan } \\
\mathrm{k} \quad & =\text { banyaknya parameter yang } \\
\text { diestimasi dalam model. }
\end{array}
$$


3. Uji signifikansi individual (Uji-t)

Uji t digunakan untuk menguji secara parsial masing-masing variabel. Hasil uji $t$ dapat dilihat pada tabel coefficients pada kolom sig (significance). Jika probabilitas nilai $\mathrm{t}$ atau signifikansi $<0,05$, maka dapat dikatakan bahwa terdapat pengaruh antara variabel bebas terhadap variabel terikat secara parsial.

Namun, jika probabilitas nilai t atau signifikansi $>0,05$, maka dapat dikatakan bahwa tidak terdapat pengaruh yang signifikan antara masing-masing variabel bebas terhadap variabel terikat.

\section{HASIL PENELITIAN}

Uji Koefisien Regresi Linier Berganda a. Uji Simultan F

Digunakan untuk mengetahui hubungan antara variabel independent danvariabel dependent, apakah variabel Bukti Langsung (X1), Kehandalan (X2), Daya Tanggap (X3), Jaminan (X4), Empati / Perhatian (X5) benar-benar berpengaruh secara simultan (bersama-sama) terhadap variabel dependen Y (kepuasan pasien).

\begin{tabular}{|c|c|c|c|c|c|c|}
\hline \multicolumn{7}{|c|}{ ANOVA $^{b}$} \\
\hline \multicolumn{2}{|c|}{ Model } & $\begin{array}{l}\text { Sum of } \\
\text { Squares }\end{array}$ & Df & Mean Square & $\mathrm{F}$ & Sig. \\
\hline \multirow[t]{3}{*}{1} & Regression & 3.364E17 & 2 & $1.682 \mathrm{E} 17$ & 172.944 & $.000^{\mathrm{a}}$ \\
\hline & Residual & $4.376 \mathrm{E} 16$ & 45 & $9.725 \mathrm{E} 14$ & & \\
\hline & Total & $3.802 \mathrm{E} 17$ & 47 & & & \\
\hline
\end{tabular}

a. Predictors: (Constant), DPK, NPF

b. Dependent Variable: Mudharabah

Dari hasil uji $\mathrm{F}$ pada penelitian ini didapatkan nilai $\mathrm{F}$ hitung sebesar 172,944 dengan angka signifikansi ( $\mathrm{P}$ value) sebesar 0,000. Dengan tingkat signifikansi 95\% ( $\alpha=0,05)$. Angka signifikansi (P value) sebesar $0,000<0,05$. Atas dasar perbandingan tersebut, maka H0 ditolak atau berarti variabel NPF dan DPK berpengaruh secara signifikan secara bersama-sama terhadap pembiayaan mudharabah.

b. Koefisien Determinasi.

Koefisien determinasi $\left(\mathrm{R}^{2}\right)$ dilakukan untuk melihat adanya hubungan yang sempurna atau tidak, yang ditunjukkan pada apakah perubahan variabel bebas (Non 
Performing Finance, dan Dana Pihak

Ketiga) akan diikuti oleh variabel.

terikat (Pembiayaan Mudharabah) pada proporsi yang sama. Pengujian ini dengan melihat nilai $\mathrm{R}$ Square (R2). Nilai koefisien determinasi adalah antara 0 sampai dengan 1 . Selanjutnya nilai $\mathrm{R}^{2}$ yang kecil berarti kemampuan variabel-variabel independent dalam menjelaskan variasi variabel dependent amat terbatas. Nilai yang mendekati 1berarti variabel-variabel

independent memberikan hampir semua informasi yang dibutuhkan untuk memprediksi variasi dependent (Ghozali, 2005).

Nilai yang dipakai dalam penelitian ini adalah nilai Adjusted R2 karena nilaiini dapat naik atau turun apabila satu variabel bebas ditambahkan ke dalam model yang diuji. Nilai Adjusted R2 dapat dilihat pada tabel berikut ini:

\begin{tabular}{|c|c|c|c|c|c|c|c|c|c|c|}
\hline \multicolumn{11}{|c|}{ Model Summary $^{\text {b }}$} \\
\hline \multirow[b]{2}{*}{$\begin{array}{l}\text { Mo } \\
\text { del }\end{array}$} & \multirow[b]{2}{*}{$\mathrm{R}$} & \multirow[b]{2}{*}{$\begin{array}{c}\mathrm{R} \\
\text { Squa } \\
\text { re }\end{array}$} & \multirow{2}{*}{$\begin{array}{c}\text { Adjust } \\
\text { ed R } \\
\text { Squar } \\
\text { e }\end{array}$} & \multirow{2}{*}{$\begin{array}{c}\text { Std. } \\
\text { Error } \\
\text { of the } \\
\text { Estimat } \\
\mathrm{e}\end{array}$} & \multicolumn{5}{|c|}{ Change Statistics } & \multirow[b]{2}{*}{ Durbin-Watson } \\
\hline & & & & & $\begin{array}{c}\mathrm{R} \\
\text { Square } \\
\text { Change }\end{array}$ & $\begin{array}{c}\text { F } \\
\text { Chan } \\
\text { ge }\end{array}$ & df1 & df2 & $\begin{array}{c}\text { Sig. F } \\
\text { Chan } \\
\text { ge }\end{array}$ & \\
\hline 1 & $\begin{array}{r}.941 \\
\mathrm{a}\end{array}$ & .885 & .880 & $\begin{array}{r}3.119 \mathrm{E} \\
7\end{array}$ & .885 & $\begin{array}{r}172.9 \\
44 \\
\end{array}$ & 2 & 45 & .000 & .363 \\
\hline
\end{tabular}

a. Predictors: (Constant), DPK, NPF

b. Dependent Variable: Mudharabah

Dapat dilihat bahwa nilai Adjusted

variabel dependent (Pembiayaan

R2 adalah sebesar 0,88. Hal ini dapat Mudharabah) sebesar $88 \%$, sedangkan diartikan bahwa variabel independent sisanya diterangkan oleh faktor lain (Non Performing Finance, dan Dana yang tidak diteliti.

Pihak Ketika) dapat menjelaskan

c. Analisis Regresi Berganda.

\section{Coefficients $^{\mathrm{a}}$}

\begin{tabular}{|c|c|c|c|c|c|c|}
\hline \multirow{2}{*}{\multicolumn{2}{|c|}{ Model }} & \multicolumn{2}{|c|}{$\begin{array}{l}\text { Unstandardized } \\
\text { Coefficients }\end{array}$} & \multirow{2}{*}{$\begin{array}{c}\begin{array}{c}\text { Standardized } \\
\text { Coefficients }\end{array} \\
\text { Beta } \\
\end{array}$} & \multirow[b]{2}{*}{$\mathrm{t}$} & \multirow[b]{2}{*}{ Sig. } \\
\hline & & B & Std. Error & & & \\
\hline \multirow[t]{2}{*}{1} & (Constant) & $6.756 \mathrm{E} 8$ & $5.988 \mathrm{E} 7$ & & 11.283 & .000 \\
\hline & NPF & 2.264 & .358 & .570 & 6.329 & .000 \\
\hline
\end{tabular}




\begin{tabular}{|c|c|c|c|c|c|}
\hline DPK & .021 & .004 & .413 & 4.581 & .000 \\
\hline
\end{tabular}

a. Dependent Variable: Mudharabah

$\mathrm{Y}($ Mudharabah $) \quad=\mathrm{C}+0,570$

$(\mathrm{X} 1)+0,413(\mathrm{X} 2)$

Persamaan di atas dapat dijelaskan

sebagai berikut :

1. Nilai 0,570 pada variabel Non Performing Finance atau NPF (X1) adalah bernilai positif, itu artinya ada pengaruh Non Performing Finance terhadap pembiayaan mudharabah sebesar 0,570 terhadap pembiayaan mudharabah.

2. Variabel Dana Pihak Ketiga atau DPK berpengaruh terhadap pembiayaan Mudharabah sebesar 0,413 .

\section{E. PENUTUP}

Berdasarkan hasil analisis data yang dilakukan, dengan menggunakan SPSS, maka dapat diambil kesimpulan dari hasil analisis pada tingkat alpha $5 \%$ dan dengan dibantu program SPSS 7. Menunjukan bahwa secara bersamaan variabel Non Performing Finance dan Dana Pihak Ketiga berpengarus secara signifikan terhadap pemberian pembiayaan mudharaba yang dilihat dari angka signifikansi (P value) sebesar $0,000<0,05$. Sedangkan secara sendiri atau tunggal adalah :
1. Non Performing Finance (NPF) memiliki kemampuan mempengaruhi pembiayaan mudharabah sebesar 0,570 atau $5,70 \%$

2. Dana Pihak Ketiga (DPK) memiliki kemampuan mempengaruhi pembiayaan mudharabah sebesar 0,413 atau $4,13 \%$

\section{DAFTAR PUSTAKA}

Antonio Muhammad Syafi'I, Bank Syariah, Jakarta : Gema Insani, 2001.

Diakses melalui.

http://rapraniji.blogspot.com/20

10/10/bank-syariah.html. 12 oktober 2015Soemitra Andri, Bank dan Lembaga Keuangan Syariah, Jakarta : Kencana, 2009.

Diakses melalui. http://www.sarjanaku.com/2012/ 06/bank-syariah-pengertianprinsip-tujuan.html. Tanggal 15 Oktober 2015.

\section{Diakses}

melalui.http://www.banksyariah. net/2012/07/pengertian-bank- 
syariah_19.html.Tanggal

Oktober 2015.

Gujarati, Damodar. Ekonometri Dasar ,Jakarta, Erlangga,2004.

Ismail. Perbankan Syariah,Jakarta : Kencana, 2014.

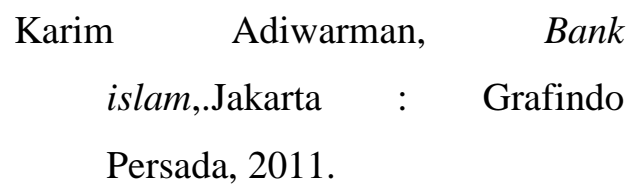

Kasmir, Bank dan Lembaga Keungan Lainnya, Jakarta : Raja Grafindo, 2008.

Mardani, Fiqih Ekonomi Syariah, Jakarta : Kencana Pramedia, 2012.
Rizal Yaya, dkk, Akuntansi Perbankan Syariah, Jakarta : Salemba Empat, 2009.

Rosadi, Dedi. Ekonometrika dan Analisis Runtun Waktu Terapan Dengan Eviews. Kajian Ekonomi, Bisnis dan Keuangan. Yogyakarta : CV. Andi Offset,2011

Sjahdeini Remy Sutan, Perbankan Syariah, Jakarta : Kencana Prenadamedia Group, 2014 